\title{
Clipping and long-term grazing effects on biomass and car- bohydrate reserves of Indian ricegrass
}

\author{
APOLLO B. ORODHO AND M.J. TRLICA
}

\section{Abatract}

Long-term heavy graxing had little effect on root and crown blomass of Indian ricegrass (Oryzopsis hymenoides [Roem. and Schult.] Ricker), nor did it significantly affect the total nonstructural carbohydrate (TNC) reserve levels or the seasonal cycle of reserves in this grass. Fifty years of protection from livestock use had not resulted in ecotypic differentiation in Indian ricegrass for these variables. Clipping reduced crown blomass more than root biomass and removal of $90 \%$ of the aboveground biomass resulted in more than a $50 \%$ reduction in crown biomass and reserve carbohydrate pool.

Two commercial strains of Indian ricegrass ('Nezpar' and 'Paloma') were compared with native Chaco Canyon strains in a uniform garden study. The Nezpar strain was superior to Paloma and the Chaco Canyon strains in production of crown biomass and TNC reserves at the more mesic garden site. The native strains from the more arid Chaco Canyon site were superior to both cultivated strains in production of roots. The native Chaco Canyon strains were little affected by clipping and have promising genetic potential for tolerance of drought and heavy grazing.

Key Words: Indian ricegrass, Oryzopsis hymenoides, heavy grazing, ecotypic differentiation, belowground biomass, carbohydrate reserves

A plant is considered to be a source-sink system where active photosynthetic tissue produces compounds which are used for maintenance and growth, stored in situ, or translocated to other sites of utilization or storage (Burt 1964, Maggs 1964, Neales and Incoll 1968). Deregibus et al. (1982) stated that a reduction of carbohydrate reserves resulting from defoliation after the peak growth period might be caused by a reduction in the leaf area and assimilate production after active aboveground growth had ceased, when meristematic activity was low, and when there were other demands for assimilates below ground. They pointed out that this was at a time when carbohydrates were normally being produced in excess of demand, hence they could be transported to belowground structures for root growth or maintenance, or be converted to long-chain carbohydrates for future growth demands.

Labile carbohydrate reserves are a major source for carbon for regrowth after defoliation (Graber 1931, Cook 1966, Youngner 1972, White 1973, Trlica 1977, Deregibus et al. 1982). However, some researchers have been critical of the role of reserve carbohydrates for regrowth following defoliation (May and Davidson

\footnotetext{
Authors are director, Western Agriculture Research Center, P.O. Box 169, Kakamega, Kenya; and professor, Range Science Department, Colorado State University, Fort Collins 80523. At the time of the research, the senior author was a FAO Fellow, Range Science Department, Colorado State University, Ft. Collins 80523.

Financial assistance was provided by the Food and Agriculture Organization of the United Nations through Project KEN/80/003, the U.S. Department of Agriculture Competitive Grants Program on Desertification, and Colorado State University Agricultural Experiment Station through Project 100.

The authors would like to thank Drs. Charles Bonham, Robin Cuany, Mark Brick, and Wayne Leininger for their assistance throughout the course of this study and for their critical review of the manuscript. The U.S. Park Service, Bureau of Land Management, and Southwestern Colorado Research Center are recognized for granting permission to use their land for this study. We thank Walter $P$. Herriman and Tom Vaughan, Superintendents of Chaco Culture National Historical Park, and their staff members for use of their facilities while conducting this study. We also thank Adrian Fisher and Mark Stack for their assistance and use of their facilities for conducting the uniform garden study.

Manuscript accepted 23 March 1989.
}

1958, Moore and Biddiscomb 1964, Davidson and Milthorpe 1965, Caldwell et al. 1981). Studies that utilized radioactive carbon have given some supportive evidence for the use of storage carbohydrates in regrowth (Pearce et al. 1969, Smith and Marten 1970, Chung and Trlica 1980), but reserves may only be needed for a short time to produce the first few leaves.

Several researchers have found that carbohydrate reserve storage in grass species was not significantly affected by grazing or defoliation treatments if the grazing or defoliation was discontinued in time to allow plants to grow up and replenish reserves before fall quiescence (Sampson and McCarty 1930, McCarty and Price 1942, Hyder and Sneva 1963, Paulsen and Smith 1968, Menke and Trlica 1983). This was partially true in the case of Indian ricegrass (Trlica and Cook 1971).

Effects of grazing or defoliation may not only be seen in terms of total nonstructural carbohydrate (TNC) concentration, but also in terms of weight of the storage organs per se (Weinmann 1952). Therefore, determination of total amount of carbohydrate pools in the storage organs (pool $=\%$ TNC $\times$ biomass of the plant part analyzed), rather than just the concentration of TNC reserves, may be important in assessing regrowth potential of plants (Buwai and Trlica 1977b, Santos and Trlica 1978). Some researchers have contradicted the traditional view that grass crowns represent the major organ for storage of soluble reserves based on determination of soluble carbohydrate pools in crowns (Caldwell et al. 1981, Richards and Caldwell 1985, Richards et al. 1987). These researchers have found little correlation between crown and stem base TNC concentration or carbohydrate pools with regrowth following defoliation.

Crowns of Indian ricegrass (Oryzopsis hymenoides [Roem. and Schult.] Ricker) may provide a better indication of TNC storage reserves and defoliation effects than do roots, if crown mass and reserve levels are large. Coyne and Cook (1971) found that crowns of Indian ricegrass had higher TNC concentrations than did roots. Trlica and Cook (1971) found that crown TNC concentration in Indian ricegrass was usually mure affected by defoliation than was root $\mathrm{TNC}$ concentration.

The main objective of this study was to determine effects of previous long-term heavy grazing and clipping on root and crown biomass and nonstructural carbohydrates in crowns of Indian ricegrass. Another objective was to compare biomass and TNC variables of native and commercial strains of this species in a uniform garden environment to assess the genetic potential of the strains.

\section{Methods and Materials}

\section{Root and Crown Biomass}

\section{Chaco Canyon In Situ Study}

An experiment was conducted within and adjacent to the Chaco Canyon Culture National Historical Park (Chaco Canyon) in northwestern New Mexico. Plots were located on a hilltop, hillside, and in a swale on both heavily grazed and protected (ungrazed) pastures at about $580 \mathrm{~m}$ elevation as described by Orodho et al. (1990) and Trlica and Orodho (1989). The 0.4-ha 
plots located outside the National Park on lands managed by the Bureau of Land Management (BLM) were fenced in April 1984 to prevent livestock grazing during 1984 and 1985 , when the study was conducted. National Park Service and BLM records indicated that this area had been heavily grazed year long by cattle, sheep, goats, and horses for more than 50 years. The area within the National Park was fenced 50 years ago to prevent livestock use within the Park. Two adjacent plots with similar soils, slope, exposure and vegetation were selected at each of the 3 topographic positions. One of the plots at each site was located within the protected area of the National Park, while the other was located on the adjacent, heavily-grazed area managed by the BLM. Plots were located at least $200 \mathrm{~m}$ from the Park boundary fence in both the grazed and protected areas at each of the 3 sites to reduce genetic exchange among the grazed and protected sites.

The long-term average annual precipitation recorded at the headquarters of the National Park was $240 \mathrm{~mm}$. Precipitation at the Chaco Canyon site was 110 and $130 \%$ above normal in 1984 and 1985, respectively. Most of the precipitation comes during the summer and fall months. The mean monthly temperature ranges from 5 to $35^{\circ} \mathrm{C}$ and the monthly mean minimum temperature ranges from -11 to $11^{\circ} \mathrm{C}$. Soils at the study area are a sandy loam.

Two shrubs, winterfat (Eurotia lanata [Pursh] Nutt.) and fourwing saltbush (Atriplex canescens [Pursh.] Nutt.) were dominant in the overstory vegetation at the Chaco Canyon study site. The most common grasses were Indian ricegrass, galleta (Hilaria jamesii [Torr.] Genth.), blue grama (Bouteloua gracilis [H.B.K.] Lag. ex Steud.), and bottlebrush squirreltail (Sitanion hystrix [Nutt.] J.G. Smith). Eriogonum spp. and Russian thistle (Salsola kali L.) were common forbs in the area. Orodho et al. (1990) found that previous heavy grazing at this research area had resulted in a reduction of fourwing saltbush; however, there had been little effect on grass cover, density or production. Density of Indian ricegrass at the Chaco Canyon study site was only 1.5 plants $/ \mathrm{m}^{2}$, whereas density of plants in the uniform garden study were 6-9 plants $/ \mathrm{m}^{2}$. However, Indian ricegrass plants were much larger and grew in association with a number of other species at the Chaco Canyon study site, so competition within the community could have affected results of the in situ field study (Mueggler 1972).

The experiment was a randomized block design which consisted of $\mathbf{2}$ former grazing intensities (heavily grazed and ungrazed for $\mathbf{5 0}$ years) and 4 defoliation intensities $(0,30,60$, and $90 \%$ removal of photosynthetic tissue-estimated). The 3 topographic sites served as replications. Four plants within each plot assigned to each defoliation treatment were randomly selected at each date of sampling. Four additional plants were selected from each defoliation intensity for sampling in 1985 at the quiescence stage. Defoliation was done at anthesis in either early June 1984 or late May 1985 for those plants that would be sampled at quiescence in late November 1985. The 4 selected plants were excavated and only crown material was retained during the 1984 sampling. These plants were collected at the second leaf stage (late April), anthesis (early June), maturity (late July), and quiescence (late November) phenological stages in 1984. The fifth sample period was at quiescence in late November of 1985 , when roots as well as crowns were sampled with a 13- $\times 24-\mathrm{cm}$ coring device. These last samples were collected using the same technique and equipment described in the next section to assess root and crown weights in the Cortez uniform garden study.

\section{Cortez Uniform Garden Study}

The Cortez study site used for the uniform garden experiments was located at the Southwestern Colorado Research Center near Yellow Jacket, Colorado, which is about $24 \mathrm{~km}$ north of Cortez. The Center is located in the dryland farming region of the south- western corner of Colorado at about $2,130 \mathrm{~m}$ elevation. The Center receives annual precipitation of about $360 \mathrm{~mm}$, half of which falls as snow during the winter months. Precipitation in 1984 and 1985 was 105 and $120 \%$ of normal, respectively. There is a frost-free period of 120 days. The monthly mean maximum temperature for this area is normally under $33^{\circ} \mathrm{C}$, while the monthly mean minimum temperature is above $-12^{\circ} \mathrm{C}$. This is quite similar to the temperature regime at Chaco Canyon, but precipitation is much greater at the Cortez site.

The principal soil series at the Cortez study site is representative of major acreages of the agricultural land in the area and is silty clay loam soil. These soils have a high water-holding capacity and store winter moisture upon which success of agriculture in the basin is dependent. Topography of the region consists almost entirely of rolling hills and the dominant vegetation types are grassland and pinyon-juniper woodland.

Two strains of Indian ricegrass were obtained from the Chaco Canyon study site. Transplants were excavated from 3 heavily grazed sites adjacent to exclosures on the hilltop, hillside, and swale locations. The transplants from each of the 3 topographic locations were combined in equal proportions to constitute the grazed strain. Similarly, transplants from sites adjacent to plots within the Chaco Culture National Historical Park were combined in equal portions from similar topographic positions to constitute the ungrazed strain.

Grazed and ungrazed plots were located approximately $400-\mathrm{m}$ apart to reduce pollen and seed transport between the 2 populations. Two other strains tested in the uniform garden experiments, 'Paloma' and 'Nezpar', are commercially released cultivars of Indian ricegrass. Paloma transplants were obtained from agronomic plots at the Cortez study site, while Nezpar transplants were obtained from a seed production field near Dolores, Colorado, approximately $25 \mathrm{~km}$ northeast of the Cortez study site.

All transplants were excavated in April of 1984, reduced to approximately the same basal area $\left(135 \mathrm{~cm}^{2}\right)$, and potted before being transported to the Cortez study site. Each plant was subdivided into 4 equal-sized bunches and immediately planted into a well-prepared seedbed at $30-\mathrm{cm}$ plant and row spacings. Weeding was done periodically by hand. We assumed that little intra-plant competition would occur during the 2 years of study.

The uniform garden experiment was a split-split-plot design having factorial arrangement of treatments with 4 replications. Two nitrogen $(\mathrm{N})$ treatments $(0$ and $50 \mathrm{~kg} / \mathrm{ha}$ ) composed the main plots, 2 clipping treatments ( $90 \%$ of active photosynthetic material clipped and unclipped) made up the sub-plots, and the 4 strains of Indian ricegrass were the sub-sub-plots. Five transplants of each strain of Indian ricegrass were planted in a row within each treatment. Nitrogen was applied in early June of 1984 and in late May of 1985 , while clipping was done at the anthesis stage of phenological development in both years. The nitrogen fertilizer application had no significant $(P>0.05)$ effect on any measured parameter; therefore it will not be discussed further in this paper.

Root and crown samples were collected in early August at the end of the growing season immediately following the 1985 aboveground biomass harvest. One of 5 plants was selected at random from each treatment in each replication to be collected. A cylindrical sampling core of $13-\mathrm{cm}$ diameter and $24-\mathrm{cm}$ long, with a sharp cutting edge, was placed directly over the selected plant crown and hammered into the ground. We estimate that this core would sample approximately $60-80 \%$ of the individual plant root biomass and $100 \%$ of the crown biomass, with little contamination of root biomass by neighboring plants. The roots and crowns within the core sample were obtained by digging around the metal core and excavating it. The crowns were separated from the roots, with obvious decayed materials being discarded, and the live crown 
tissue was washed with tap water and placed into a glass jar. The crown tissue was covered with $95 \%$ ethanol immediately following washing to reduce enzymatic activity, and then sealed tightly.

Crown samples were taken to the laboratory where jars were placed, with their lids open, in a forced-draft oven at $60^{\circ} \mathrm{C}$. Ethanol was evaporated and the samples completely dried before they were weighed and then ground in a Wiley mill to pass through a 0.5 -mm screen. The ground samples were kept in sealed polyethylene bags prior to laboratory analysis.

Plant roots were separated from crowns immediately after they were obtained from the field. Roots were removed from soil by a floatation method (McKell et al. 1961) using 0.05-mm screens. The root samples were oven-dried at $60^{\circ} \mathrm{C}$ and weighed.

\section{Carbohydrate Analysis}

The prepared crown samples from the Cortez and Chaco Canyon study sites were taken to a laboratory for TNC analysis. TNC was extracted from each $0.5-\mathrm{g}$ plant sample with $0.2 \mathrm{~N}$ sulphuric acid (Smith et al. 1964). The extracts were then used to determine TNC concentration on a glucose-equivalent basis by using an iodometric titration developed by Heinze and Murneek (1940), but using modified reagents as suggested by the Association of Official Analytical Chemists (1965). Standard curves were determined for each stock solution. The TNC percentages were multiplied by the weight of the plant organ to determine carbohydrate pool quantity.

\section{Data Analysis}

All data on root and crown weights, TNC concentration, and carbohydrate pools were analyzed using analysis of variance procedures (Steel and Torrie 1980). The calculated F-values were tested at the $\alpha=0.05$ level of probability, and if significant $(P \leq 0.05)$ interactions were found, then analysis within levels of a factor were conducted. When significant $(P \leq 0.05)$ differences were detected, Duncan's New Multiple Range Test was used to separate significant $(P \leq 0.05)$ means.

\section{Results and Discussion}

\section{Root and Crown Biomass}

Long-term heavy grazing (i.e., greater than 50 years) did not significantly affect root biomass of Indian ricegrass in the top 24 $\mathrm{cm}$ of soil at the Chaco Canyon study site (data not shown). There were, however, significant differences in root biomass (Fig. 1)

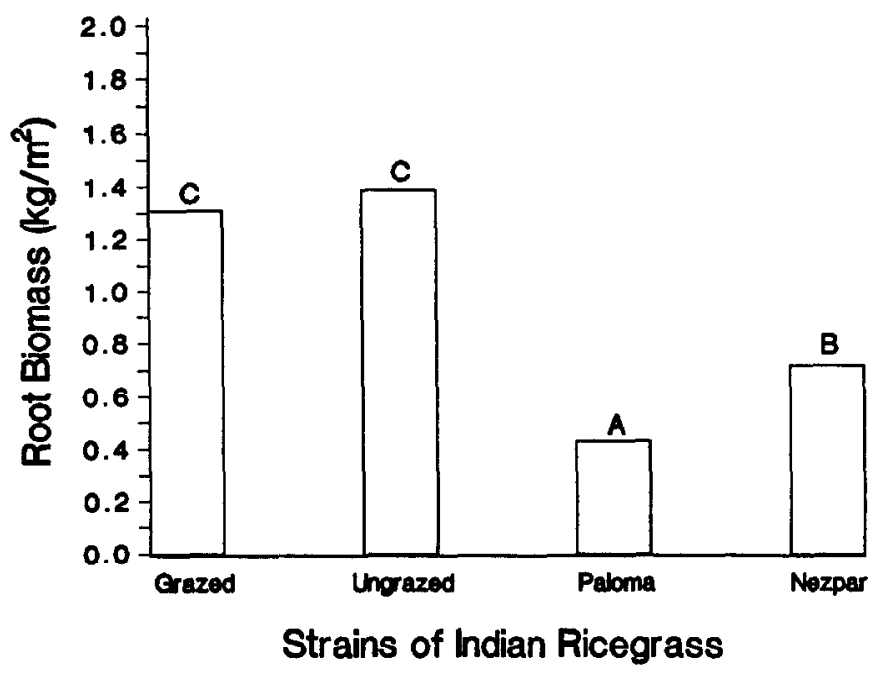

Fig. 1. Root blomass for 4 strains of Indian ricezrass at the Cortez common garden site in Auguat 1985. Values are the average over replications, fertilization, and clipping treatments. Means labeled with similar letters are not significantly different $(P>0.05)$. among the 4 strains of Indian ricegrass transplanted into the uniform garden at the Cortez site. No significant differences in root biomass among the grazed and ungrazed strains of Indian ricegrass from the Chaco Canyon study site were found. It should be noted that these 2 strains had greater root biomass than did either of the 2 cultivated strains of Paloma and Nezpar (Fig. 1). Paloma had the lowest root biomass among the 4 strains of Indian ricegrass tested in the transplant garden at the Cortez study site. Greater root biomass for the 2 native strains of Indian ricegrass should be advantageous under droughty conditions.

Defoliation at 30,60 , or $90 \%$ removal of photosynthetic tissue at anthesis in early June had little effect on root biomass of in situ Indian ricegrass at the Chaco Canyon study site. Clipping Indian ricegrass at anthesis in the Cortez uniform garden also had little effect on root biomass and there was no significant clipping- $x$ strain interaction. The present research supported earlier work reported by Buwai and Trlica (1977a), who found no change in total root weights of blue grama and western wheatgrass (Agropyron smithii Rydb.) after defoliation. Results of this research did not support that reported by Deregibus (1983), who found a reduction of root biomass in Paspalum dilatum (Poir) as a result of defoliation. Santos and Trlica (1978) also found that the biomass of crowns and roots of blue grama and the root biomass of western wheatgrass were reduced by frequent defoliation. A number of other researchers have also reported reduction or stoppage of root growth following defoliation (Crider 1955, Oswalt et al. 1959, Jameson 1963, Davidson and Milthorpe 1965).

Any defoliation caused significant reductions in crown biomass of Indian ricegrass at the Chaco Canyon study site compared with unclipped plants (control) (Fig. 2). Although there were no differ-

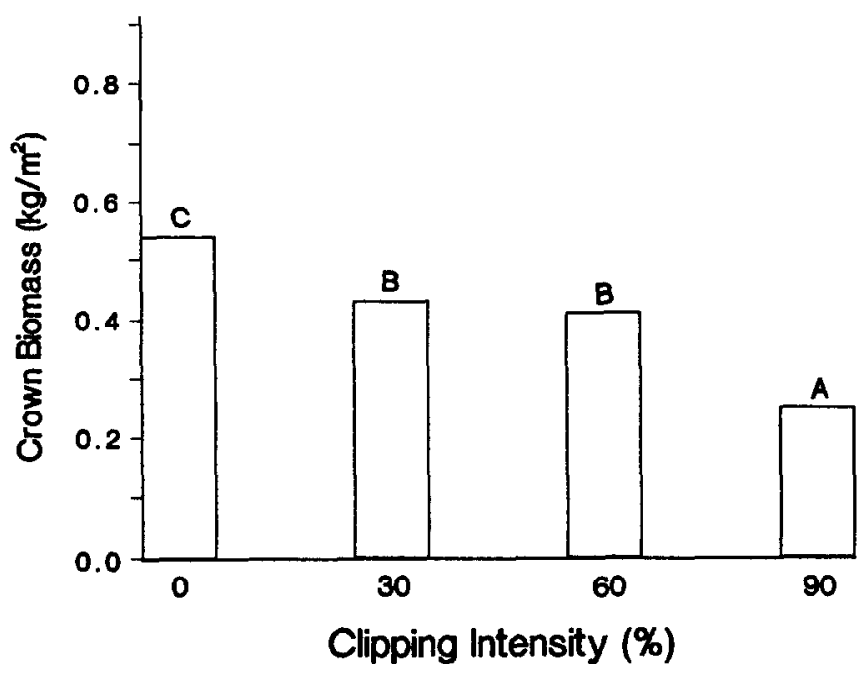

Fig. 2. Crown biomass for in situ Indian ricegrass at the Chaco Canyon study site as affected by defollation intendity. Values are the average over slope position and previous grazing hlatory. Means for the defoliation intensity labeled with the same letter are not significantly different $(P>0.05)$.

ences in crown weights of plants defoliated at 30 and $60 \%$, plants defoliated at $90 \%$ had significantly lower crown weights.

Clipping of Indian ricegrass at anthesis resulted in a significant increase in crown biomass of Nezpar, but did not cause any significant change in crown weights of Paloma or the 2 native strains taken from the Chaco Canyon study site (Fig. 3). This significant clipping-x-strain interaction was caused mainly by the reaction of the Nezpar strain to the single defoliation. These findings were not in agreement with results obtained from the defoliation treatments at the Chaco Canyon study site, where several intensities of defolia- 
clipped at 90\%. Trlica and Cook (1971) reported that TNC reserves in both roots and crowns of Indian ricegrass were usually higher among control plants than they were for heavily defoliated plants. They noted that TNC concentrations were significantly lower when defoliation occurred during late spring or near maturity in the summer.

The total carbohydrate pools in crowns of Indian ricegrass at the Chaco Canyon study site following defoliations are illustrated in Fig. 5b. Defoliation at $90 \%$ resulted in the lowest total carbohydrate pool in crowns of Indian ricegrass, whereas the greatest carbohydrate pools were found in control plants. There were no significant differences in total carbohydrate pools among plants from the 30 and $60 \%$ defoliation treatments.

There appeared to be little correlation between TNC concentration and the total carbohydrate pool in crowns of Indian ricegrass (Fig. 5a \& b). The trend observed for total carbohydrate pools in crowns was more correlated with crown weights following defoliation (Fig. 2) than with TNC concentrations (Fig. 5a). Santos and Trlica (1978) found that TNC concentration in blue grama was little affected by clipping, but that total carbohydrate pools were less because of a reduction in mass.

A single clipping in the uniform garden study had no significant effect on TNC concentrations in crowns of grazed and ungrazed strains of Indian ricegrass from the Chaco Canyon study site (Fig. $6 a)$. On the other hand, clipping resulted in a significant increase in
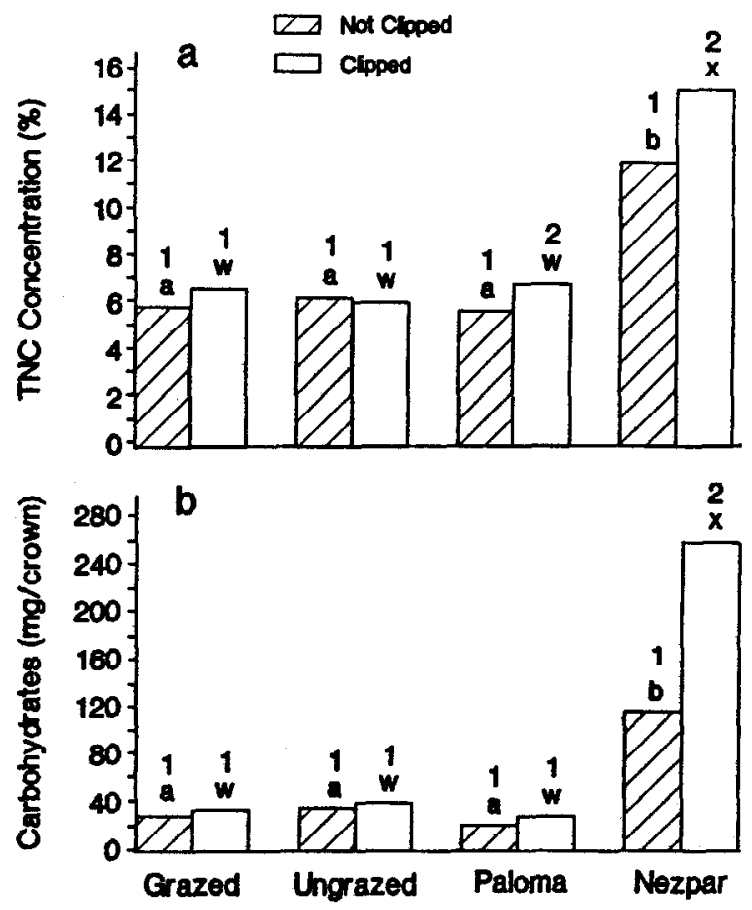

\section{Strains of Indian Ricegrass}

Fig. 6. Total nonstructural carbohydrate (TNC) concentration (a) and total carbohydrate pools (b) in crowns of 4 strains of Ind han riceernes at the Cortez uniform garden study as afiected by clipping. Valuew are the average over replications and fertiluntion treatments. The clipping treatments across the 4 otrins labeled with a similar letter are not sipnifieantly difierent (P>0.05). The clipping treatment within each strin labeled with a similiar number is not signinieantly different $(P>0.05)$.

TNC concentration in crowns of the Paloma and Nezpar strains. Clipped Nezpar plants had more than twice the TNC concentration as the other 3 strains studied. No differences were found for TNC concentrations between the clipped and unclipped plants for the grazed and ungrazed strains of Indian ricegrass.

Clipping resulted in a significant increase in the total carbohydrate pool in crowns of Nezpar, but had no significant effects on the other strains of Indian ricegrass tested (Fig. 6b). Carbohydrate pools among grazed, ungrazed, and Paloma strains were quite similar. Nezpar had the greatest carbohydrate pool in crowns of both clipped and unclipped plants compared with any of the other 3 strains tested in the uniform garden. The carbohydrate pool averaged about 5 times greater for this strain and the carbohydrate pool more than doubled with clipping. Again, carbohydrate pool size was affected more by crown weight than TNC concentration. There was a lack of correlation between TNC concentration and total carbohydrate pool in Paloma following clipping. Clipping resulted in a significant increase in TNC concentration in crowns of Paloma (Fig. 6a), but did not affect the total carbohydrate pool size of this strain (Fig. 6b).

\section{Summary and Conclusions}

Long-term heavy grazing had no significant effect on root and crown biomass of Indian ricegrass at the Chaco Canyon study site, nor did it significantly affect TNC reserves in this grass. This indicated that 50 years of protection from heavy livestock grazing pressure had not resulted in significant selection and differentiation of Indian ricegrass into an ecotype with different root and crown biomass or TNC reserve concentrations. We also found that other morphological and chemical characteristics of this grass had not been affected by long-term protection from livestock grazing (Trlica and Orodho 1989). Either long-term heavy grazing in this area has eliminated or greatly reduced nonresistant genotypes, or Indian ricegrass employs high regrowth capacity rather than defense mechanisms to overcome intense herbivory (Meijden et al. 1988, Olson and Richards 1988).

Crown biomass of Indian ricegrass was affected more by defoliation than was root biomass. Defoliation intensities affected TNC concentration and carbohydrate pools in crowns of Indian ricegrass. A $\mathbf{9 0 \%}$ defoliation intensity resulted in more than a $\mathbf{5 0 \%}$ reduction in the carbohydrate reserve pool. A seasonal trend of carbohydrate reserve depletion during initial growth and subsequent replenishment of reserves at a later growth stage was evident in Indian ricegrass. This pattern of the TNC cycle and amount of carbohydrate reserves were not affected by long-term heavy grazing.

Significant variations in root and crown biomass and in TNC concentrations existed among the 4 strains of Indian ricegrass and in response to clipping. Nezpar was superior to all other strains of Indian ricegrass tested at the more mesic Cortez uniform garden site with respect to crown biomass and carbohydrate reserves. Clipping resulted in greater crown biomass and TNC concentration of Nezpar, while clipping had little effect on the Chaco Canyon strains. This indicated that Nezpar was a better strain of Indian ricegrass to be recommended in the Cortez area with higher elevation and annual precipitation above $360 \mathrm{~mm}$.

The 2 strains of Indian ricegrass from Chaco Canyon were not different from each other but were superior to Paloma. Their superiority was particuarly evident in their greater root biomass. These 2 strains from Chaco Canyon have promising genetic potential in their tolerance to drought and long-term heavy grazing. It is recommended that these Chaco Canyon strains be further evaluated for these traits and constituted into a single improved cultivar for use in revegetation of more arid regions (precipitation less than $250 \mathrm{~mm}$ ) and at lower elevations in the western United States.

\section{Literature Cited}

Association of Official Analytical Chemiats. 1965. Pp. 498-499. In: Official methods of analysis. Assoc. Official Agr. Chem. 10th ed. Washington, D.C. 
Buwal, M., and M.J. Trilica. 1977a. Defoliation effects on root weights and total nonstructural carbohydrates of blue grama and western wheatgrass. Crop. Sci. 17:15-17.

Buwal, M., and M.J. Trilea. 1977b. Multiple defoliation effects on herbage yield, vigor and total non-structural carbohydrates of five range species. J. Range Manage. 30:164-171.

Caldwell, M.M., J.H. Richards, D.A. Johnson, R.S. Nowak, and R.S. Dzurec. 1981. Coping with herbivory. Photosynthetic capacity and resource allocation in two semiarid Agropyron bunchgrasses. Oecologia 50:14-24.

Chung, H.H., and M.J. Trlica. $1980 .{ }^{14} \mathrm{C}$ distribution and utilization in blue grama as affected by temperature, water potential and defoliation regimes. Oecologia 47:190-195.

Cook, C.W. 1966. Carbohydrate reserves in plants. Utah Agr. Exp. Sta. Research Series Logan, Utah.

Cook, C.W., and R.D. Child. 1971. Recovery of desert plants in various states of vigor. J. Range Manage. 24:339-343.

Coyne, P.I., and C.W. Cook. 1971. Seasonal carbohydrate reserve cycles in eight desert range species. J. Range Manage. 23:438-444.

Crider, F.J. 1955. Root-growth stoppage resulting from defoliation of grass. USDA Tech. Bull. 1102.

Davidaon, J.L., and F.L. Milthorpe. 1965. Carbohydrate reserves in the regrowth of cocksfoot (Dactylis glomerata L.). J. Brit. Grassl. Soc. 20:15-18.

Deregibus, V.A. 1983. Grass tillering as affected by light environment, organic reserve status, and defoliation. Ph.D. Diss. Colo. State Univ., Ft. Collins.

Deregibus, V.A., M.J. Trlica, and D.A. Jameson. 1982. Organic reserves in herbage plants: Their relationship to grassland management. pp. 315444. In: M. Rechigl, Jr. (ed.). CRC Handbook of Agricultural Productivity Vol. 1. Plant Productivity. CRC Press Inc., Boca Raton, Florida.

Graber, L.F. 1931. Food reserves in relation to other factors limiting the growth of grasses. Plant Physiol. 6:43-71.

Heinze, P.H., and A.E. Murmeek. 1940. Comparative accuracy and efficiency in determination of carbohydrates in plant material. Mo. Agr. Exp. Sta. Res. Bull. 314.

Hyder, D.N., and F.A. Sneva. 1959. Growth and carbohydrate trends in crested wheatgrass. J. Range Manage. 12:271-276.

Hyder, D.N., and F.A. Sneva. 1963. Morphological and physiological factors affecting the grazing management of crested wheatgrass. Crop Sci. 3:267-271.

Jameson, D.A. 1963. Response of individual plants to harvesting. Bot. Rev. 29:232-294.

Magss, D.H. 1964. Growth rates in relation to assimilate supply and demand. I. Leaves and roots as limiting regions. J. Exp. Bot. 15:574-583.

May, L.H., and J.L. Davidson. 1958. The role of carbohydrate reserves in regeneration of plants. Aust. J. Agr. Res. 9:767-777.

McCarty, E.C., and R. Price. 1942. Growth and carbohydrate content of important mountain forage plants in central Utah as affected by clipping and grazing. USDA Tech. Bull. 818.

Meijen, E. van der, M. Wijn and H.J. Verkaar. 1988. Defense and regrowth, alternate plant strategies in the struggle against herbivores. Oikos 51:355-363.

Menke, J.W., and M.J. Trlica. 1981. Carbohydrate reserves, phenology and growth cycles of nine Colorado range species. J. Range Manage. 34:269-277.

Menke, J.W., and M.J. Trlica. 1983. Effects of single and sequential defoliation on the carbohydrate reserves of four range species. J. Range Manage. 36:70-74.

Moore, R.M., and E.F. Biddingacomb. 1964. The effects of grazing on grassland. pp. 221-235. In: C. Barnard (ed.) Grasses and grasslands. McMillan, London.
Muezaler, W.F. 1972. Influence of competition on the response of bluebunch wheatgrass to clipping. J. Range Manage. 25:88-92.

Neales, T.F., and L.D. Incoll. 1968. The control of leaf photosynthesis rate by the level of assimilate concentration in the leaf: $A$ review of the hypothesis. Bot. Rev. 34:107-125.

Olson, B.E., and J.H. Richards. 1988. Tussock regrowth after grazing: intercalary meristem and axillary bud activity of tillers of Agropyron desertorum. Oikos 51:374-382.

Orodho, A.B., M.J. Trlica, and C.D. Bonham. 1990. Long-term heavy grazing effects on soil and vegetation in the Four Corners Region. Southwest. Natur. (in press).

Oswalt, D.L., A.R. Bertrand, and M.R. Teel. 1959. Influence of nitrogen fertilization and clipping on grass roots. Proc. Soil Sci. Soc. Amer. 23:228-230.

Paulsen, G.M., and D. Smith. 1968. Influence of several management practices on growth characteristics and available carbohydrate content of smooth bromegrass Agron. J. 60:375-379.

Pearce, R.B., G. Flssel, and G.E. Carlson. 1969. Carbon uptake and distribution before and after defoliation of alfalfa. Crop Sci. 9:756-759.

Richards, J.H., and M.M. Caldwell. 1985 . Soluble carbohydrates, concurrent photosynthesis and efficiency in regrowth following defoliation: $A$ field study with Agropyron species. J. Appl. Ecol. 22:907-920.

Richards, J.H., M.M. Caldwell, and B.E. Olson. 1987. Plant production following grazing: Carbohydrates, meristems, and tiller survival over winter. Rangeland Monitoring Symposium, Soc. Range Manage., Boise, Idaho.

Sampson, A.W., and E.C. McCarty. 1930. The carbohydrate metabolism of Stipa pulchra. Hilgardia 5:61-100.

Santos, G.L., and M.J. Trilea. 1978. Clipping effects on production and carbohydrate reserves of blue grama and western wheatgrass. pp. 384386. In: Ist Int. Range Congr., Denver, Colorado.

Smith, D., G.M. Paulsen, and C.A. Raguse. 1964. Extraction of total available carbohydrates from grass and legume tissue. Plant Physiol. 39:960-962.

Smith, L.H., and G.C. Marten. 1970. Foliar regrowth of alfalfa utilizing ${ }_{14} \mathrm{C}$-labeled carbohydrates stored in roots. Crop Sci. 10:146-151.

Steel, R.G. and J.H. Torrie. 1980. Principles and procedures of statistics. 2nd ed. McGraw-Hill Book Co., New York.

Trlica, M.J. 1977. Distribution and utilization of carbohydrate reserves in range plants. pp. 73-96. In: R.E. Sosebee (ed.) Rangeland Plant Physiology. Range Sci. Series. No. 4. Soc. Range Manage. Denver, Colo.

Trlica, M.J., and C.W. Cook. 1971. Defoliation effects on carbohydrate reserves of desert species. J. Range Manage. 24:418-425.

Trlica, M.J., Jr. and C.W. Cook. 1972. Carbohydrate reserves of crested wheatgrass and Russian wildrye as influenced by development and defoliation. J. Range Manage. 25:430-435.

Trlica, M.J., and A.B. Orodho. 1989. Effects of protection from grazing on morphological and chemical characteristics of Indian ricegrass (Oryzopsis hymenoides) Oikos (in press).

Troughton, A. 1957. The underground organs of herbage grasses. Commonwealth Bur. Pasture and Field Crops Bull. No. 44.

Weimmann, H. 1952. Carbohydrate reserves in grasses. pp. 655-660. In: Proc. Sixth Int. Grassland Cong., Penn State College, Penn.

Weinmann, H. 1961. Total available carbohydrates in grasses and legumes. Herbage Abstr. 31:255-261.

White, L.M. 1973. Carbohydrate reserves of grasses. A review. J. Range Manage. 26:13-18.

Youngner, V.B.1972. Physiology of defoliation and regrowth. pp. 292-303. In: V.B. Youngner and C.M. McKell (eds.). The Biology and Utilization of Grasses. Academic Press, New York. 